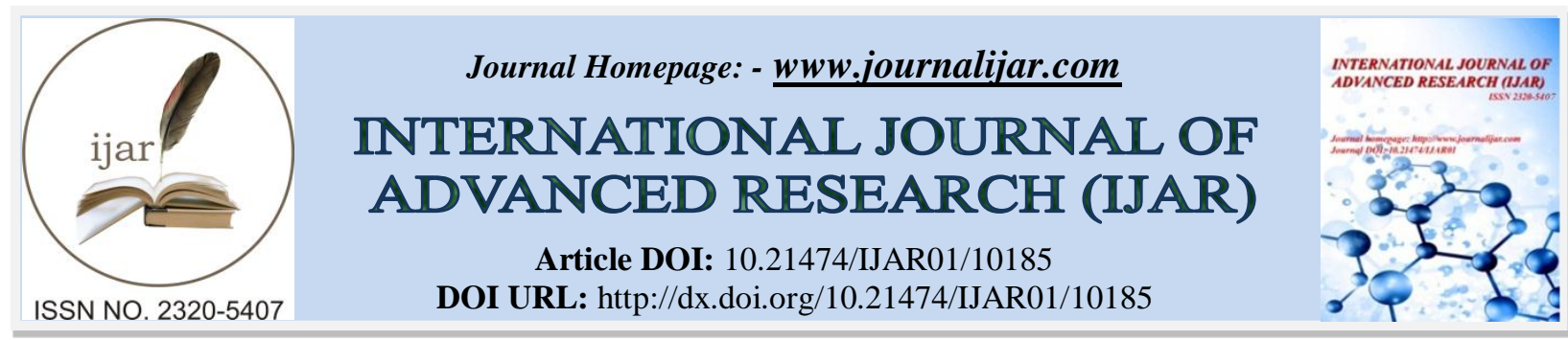

RESEARCH ARTICLE

\title{
EVALUATION OF POLITICAL POLICY OF EDUCATION MANDATORY MADRASAH DINIYAH TAKMILIYAH (ANALYSIS OF EDUCATION POLICY BASED ON REGIONAL REGULATION NO. 12 OF 2012 IN INDRAMAYU REGENCY)
}

\author{
Siti Ana Maryanah ${ }^{1}$, Muchlis ${ }^{2}$ and Thamrin Abdullah ${ }^{3}$ \\ 1. Research Scholar, Educational Management, Universitas Negeri Jakarta. \\ 2. Professor, Educational Management, Universitas Negeri Jakarta. \\ 3. Professor, Educational Management, Universitas Pakuan.
}

\section{Manuscript Info}

a.n.......................

Manuscript History

Received: 08 October 2019

Final Accepted: 10 November 2019

Published: December 2019

Key words:-

Wise Evaluation, Madrasa Diniyah

Takmiliyah Awaliyah, Education Politics

\begin{abstract}
The evaluation itself aims to find out whether the policies implemented reach the target, exceed the target or not achieve the expected target. Research on political education policy in Indramayu Regency is based on Regional Regulation No. 12 of 2012. Based on the findings and analysis of research subjects, the results can be said expressly in accordance with the vision and mission of the Indramayu District Education Office, the success of the compulsory education program has encouraged an increase in the number and quality of MDTA because it is supported by the affirmation that the MDTA diploma is a requirement for proceed to SMP / MTs in Indramayu Regency. The public response to this program is proof that the politics of education in Indramayu was accepted as an effort to prepare young people who are superior, trustful, religious, obedient and innovative. Thus this political education policy needs to be maintained and improved governance and support from various stakeholders.
\end{abstract}

Copy Right, IJAR, 2019,. All rights reserved.

\section{Introduction:-}

Every decision making in any institution, organization or industry is never separated from various interests. The intended interests can be categorized in the short term, medium term and long term, depending on the objectives to be achieved. When the goal has been achieved, then a new policy appears that can accommodate its interests as far as possible. This will tend to be repeated until there is a change of leadership in an institution or organization which may be a battle of new interests in accordance with the interests of policy makers.

Policy is a decision that has been established or a standing decision that has certain characteristics such as the consistency of attitude and repetition for the subject and object (Heinz Eulau and Kenneth Prewitt, in Reyes, 2001) the direction and purpose of education in a country. One thing is certain that any policy is always realized in the form of decisions that emphasize the implementation of actions, regardless of whether the action is ultimately implemented or not.

Corresponding Author:- Siti Ana Maryanah

Address:- Research Scholar, Educational Management, Universitas Negeri Jakarta. 
The second is manifested in the form of government attitudes, especially from the Ministry of Education and Culture which includes formal attitudes as outlined in the Decree or Ministerial Decree, and non-formal attitudes such as comments, statements, or suggestions on all matters relating to national education (Assegaf, 2005) .

Third, freeing basic education costs. Local governments must have a strong will to be able to free students from fees operational education for elementary school level. Article 31 of the 1945 Constitution (paragraph 2) expressly mandates "Every citizen is required to attend basic education and the government is obliged to finance it". At present it has been given freedom, it's just that at the level of implementation there are still levies imposed by the school and this is burdensome for parents of students.

Fourth, curriculum improvement. Education must be directed at an open and multi-meaning system and the empowerment of students that lasts throughout life. Therefore, the education curriculum must be able to form intelligent, faithful, devout, noble, and have the freedom to develop their potential. Education must also be held by giving examples, building will, and developing students' creativity in the learning process.

Fifth, the appreciation of educators. The government must be more serious in increasing the qualifications, professionalism and welfare of teachers. This is important because teachers are the main pillars in education and national development. Without professional and prosperous teachers, education is impossible to advance and be competitive. Of the five alternative solutions to the problem of education as described above, the researcher highlights the third alternative, namely compulsory education and the government that is required to finance it. This compulsory education policy is focused on Indramayu Regency which has formulated and produced public policies in the form of Regional Regulations. The regulation mandates compulsory education for Madrasah Diniyah Takmiliyah in Indramayu Regency. In accordance with its basic principles, Madrasah Diniyah Takmiliyah is one type of non-formal Islamic religious education that organizes Islamic education as a complement to general education students. MDTA is generally intended for elementary school age children with a learning period of 6 years. The researcher evaluates the intended policy based on the understanding that: Education is a means to educate the nation's life and become a very important sector.

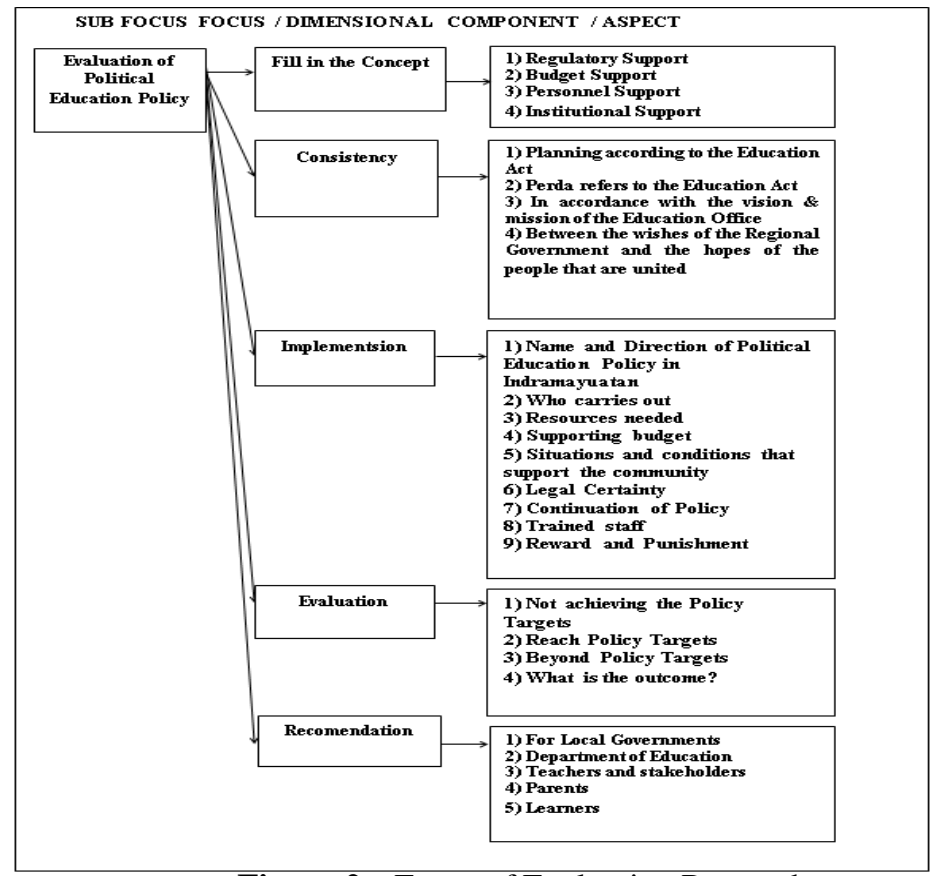

Figure 2:- Focus of Evaluation Research.

The purpose of this study was to obtain information about how the implementation of political education policies in Indramayu Regency. The education policies seen are the contents of the policy, the consistency of the policy, the implementation of the policy and the evaluation of the policy, which in turn gives birth to recommendations to be used as input for the government in making policies related to the politics of education. 


\section{Literature Review:-}

Evaluation is nothing other than a part or stage in the policy process. Evaluation is interpreted by William Dunn (in Nugroho, 2011) as appraisal, rating, and assessment to interpret the results of the program through the provision of unit values. Evaluation covers several aspects which are as important as those aspects covered in the policy analysis activities in the previous stage.

The concept of evaluation is one step in the cycle of implementing a policy. The results of the evaluation can be used as a form of input or correction and recommendations in decision making. Included in this is useful for improvements in the implementation of a policy both being implemented and policies that have been made. Evaluation is done on a value that does require certainty. Specifically Fitzpatrick, Sanders and Worthen (2004) define evaluation, namely: "Evaluation is to determine or fix the value of to examine and judge". On the other hand P. Tochot, et al, (2012). views policy with the following explanation: "evaluation helps stakeholders to find out what works and what doesn't. Done well, it provides a road map for an organization to improve the processes, participant outcomes, and to have a bigger impact on the organization and the community.

The program is a technical operational form of a public policy which is popularly referred to as public policy, which is a decision made by the state, especially the government, as a strategy to realize the objectives of the country concerned. (Dwijowijoyo, 2008). This decision must be obeyed and in effect binding all the people (external policy) or employees (internal policy).

Wholey, Hatry and Newcomer (2010) define: "A program is a set of resources and activities directed toward one or more common goals". A program is a collection of resources and activities directed at achieving one or more specific objectives. A program can consist of a load of limited activities in one.

institution or a charge of complex activities carried out in many places involving one, two or more public communities, whether government agencies, non-profit organizations, or even private parties. The implementation of these activities is carried out based on rules or regulations of public policy that are generally agreed upon as correct.

Cronbach in Fitzpatrick, Sanders and Worthen (2004) states "Program is a term that can be defined in many ways. In its simplest sense, a program is a "standing arrangement that provides for a ..... service". Program is a term that can be defined in many ways. Simply explained that the program is the arrangements provided to meet and provide certain services. When an issue that concerns a common interest is deemed necessary to be regulated, the provisions of that issue become a policy to be compiled and agreed upon by the authorized officials. When the policy is determined to be a public policy, such as Law, Government Regulation or Presidential Regulation including Ministerial Regulation, the policy must be followed up into a program that must be implemented to achieve the desired goals.

Joseph Wholey stated that program evaluation is concerned with the application of various systematic methods to answer questions about program implementation and results. Program evaluation must be able to describe all program processes produced by program makers and program managers. Evaluation is a reference to the strategic issues of a program as an important question that needs to be answered.

David Royse, Bruce A. Thyer, and Deborah K. Padgett (2010) state that program evaluation is, "A form of appraisal, using valid and reliable research methods, that examines the processes or outcomes of an organization that exists to fulfill some social need ".

Program evaluation is a form of assessment using valid and reliable research methods, which examines the process or results of an effort made in an organized manner to meet some social needs. Program evaluation research is useful when used to explain debates about the phenomenon of a policy program.

Program evaluation helps the decision making process going forward in a more rational and measurable way to improve the understanding of all parties involved in decision making. In other words, program evaluation must be understood and used as a decision-making tool for managing various levels of the policy system in implementing a program, not as an instrument of judgment, whether positive or negative. Evaluations must provide a basis for better decision making, by highlighting problems and formulating appropriate recommendations for improving a program. 
Implementation of policy in principle is the way implemented so that a policy can achieve its objectives ". (Dwijiwijoto, 2003). Explained by Putt and Springer (1989), policy implementation is a series of activities and decisions that facilitate policy statements in formulations manifested into organizational practices.

Tangkilisan (2003) implementing policies requires a number of decisions and actions by the School Principal. There are four important factors in implementing policies, namely communication, source, disposition or attitude and bureaucratic structure. To implement the policy, there are two possible choices of steps, namely: directly implementing in the form of programs, or can, through the derivate policy (derivative) of the public policy. Generally described by Dwijowijoto (2003).

\section{Research Methods:-}

This research was conducted at the District Education Office of Indramayu. Because this research focuses on policy evaluation that concerns Indramayu Regional Regulation No. 12 of 2012 concerning Compulsory Education for Diniyah Takmiliyah. For interviews with the Head of the Education Office, for interviews with Principals in MDTA Schools, interviews with Indramayu DPRD members in the Indramayu DPRD Building especially with the Commission in charge of Education and Culture. While the data obtained from observations of the teachers were done in the schools that were targeted for the study, namely: 5 best MDTs in Indramayu.

This research is a policy evaluation research. In the content analysis that is reviewed in policy research in general, the results of policies ranging from the legislative process at the district level to the executive policy products, from regional leaders to implementation in the field.

Figure 1:- Diniyah Takmiliyah Compulsory Education Policy Research Design

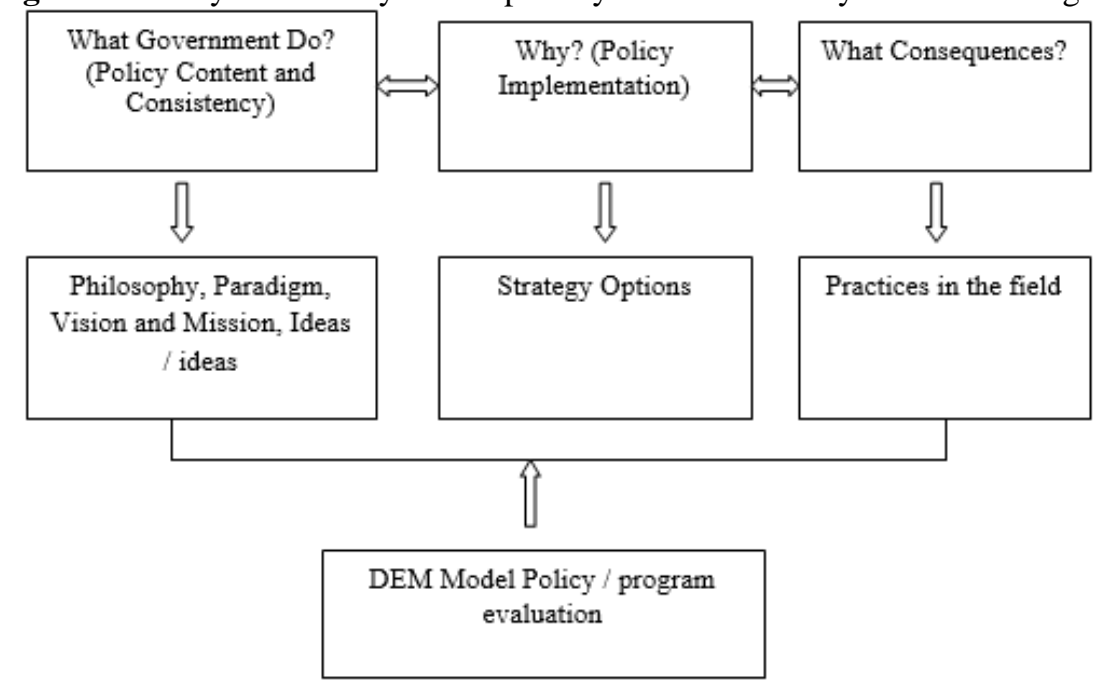

In Indonesia, policy analysis, especially policy analysis in the field of education is still rarely found, even though education is the center of the area of public policy. Therefore, the literature on policy studies is still scarce. However, as is usual in science, according to Philips, policy analysis follows the methodology and logic of the positivism system. (Philips, 1983). As Amy said cited by Heineman in Persons (2001) that positivism methodology still dominates policy analysis, despite the fact that its intellectual foundation was shaken at least a decade ago. Positivism survives because it limits it in such a way that it is politically satisfying, the types of problems that can be analyzed in an analytical way.

In Starling's (2008) view, this evaluation research method is categorized as an implementation evaluation method. Evaluation of implementation differs from the definition of Impact evaluation or evaluation of Impact which is intended to see the impact or consequences that result from the implementation of an activity (summative evaluation). Evaluation of implementation is more descriptive about what happened and why. This in Starling's terms is called formative evaluation or process evaluation. The evaluation process proposed by Starling compares what happens and is carried out in the implementation of the policy with the results obtained and also compared with the expected results (which are usually contained in legislation). 


\section{Data being evaluated:}

The data to be collected in this study includes the facts and information about MDT policies in Indramayu Regency which consist of evaluation components in the research, including:

1. Policy content, is a detailed description of the input, which is the source of program support that is utilized and needed so that the implementation of activities can run to produce policy outputs

2. Consistency, is a detailed description of the process in the form of program implementation activities that describe the activities or activities that occur or are carried out during the implementation of the policy, particularly in the process of processing program support inputs into outputs of policy results.

3. Evaluation, is a detailed description of the implementation and output of the program results in the form of an output which is produced and expected directly from the achievement of an activity in the form of physical and or non-physical

4. Recommendation, is a detailed description of the outcome of the policy benefits obtained in everything that reflects the functioning of the outcome of the educational policy politics that are evaluated.

\section{Grid of Data Collection Tools:}

Data collection tools used are interview guidelines, observation and document review to obtain primary data, as well as guidelines for focused discussion and survey questionnaires to obtain additional secondary data (table 3.2). The data obtained is used for analysis and interpretation. The details of the data used to be used as a limitation in developing the process of collecting data when conducting interviews, observations and study documents. is:

1. Data showing resources that are utilized in implementing MDT policies in Indramayu

2. Data showing the implementation of policies carried out in MDT operations in Indramayu Regency.

3. Data showing outputs generated by MDT policy in Indramayu Regency

4. Data showing the benefits obtained from the implementation of MDT education political policies in Indramayu Regency.

5. Data showing the impact of changes or perceived value from the implementation of MDT education political policies in Indramayu Regency.

The validation process is carried out through a theoretical study of the component concepts and aspects to be evaluated, the indicators up to the elaboration and writing into interview questions, discussion material in focused discussion, observational facts, and questionnaire items. The process to improve the items of the statements in the questionnaire and interview question items is carried out to test the content validity and face validity. Content validity is the extent to which the measuring instrument represents the domain of the theory that is to be adequately measured. (Kaplan \& Saccuzo, 1993) while face validity is the validity of a measuring instrument based on its external appearance.

The improvement of content validity is carried out by submitting statement items to experts as academics who are competent in the fields of science and management research methods. The experts instruct the refinement of the statement items by improving the use of sentences and words that represent the aspects to be measured, improving the statement items that are not clear in their meaning, and uniting items that have similar meanings. Improvement of statement items results in new statement items that are better and assessed by experts already representing the measurement of the domain to be measured.

Improvements in face validity are carried out by showing items of statements to prospective respondents. As well as to determine the clarity of the statement items, as well as the level of difficulty of understanding. Display validity is the validity of a measuring instrument based on its external appearance, to show the respondent whether the items of the statement are understood in accordance with the purpose of the measurement.

In evaluation research with a qualitative approach, researchers are the main instrument in capturing data. Patton (in Wirawan, 2011) states that there are four elements that must be fulfilled by researchers in capturing qualitative evaluation data, namely (1) researchers must be as close as possible to the object of evaluation in order to understand in detail the situation, (2) researchers must capture facts -facts, (3) qualitative data contains pure descriptions of people, activities and interactions, (4) qualitative data consists of direct quotes from people, including what they say and write (Wirawan, 2011). 
Data and information are collected through the use of relevant data collection methods. Some methods used to collect data and information for program evaluation include document review, interviews, observation, focused discussion, and survey questionnaires.

\section{Results and Discussion:-}

The definition of Diniyah Takmiliyah Awaliyah is Islamic education at the basic level beyond formal education. Based on its function and role in the context of education management, Diniyah Takmiliyah is a non-formal institution as a forum for education about Islam for children with various levels including Awaliyah, Wustho, Ulya. With an emphasis on Islamic education, Diniyah Takmiliyah education must have more quality in order to become more competent learners in science. From the description of Diniyah Takmiliyah Awaliyah as an embodiment of Perda Number 12 of 2012 concerning Compulsory Education for Diniyah Takmiliyah in Indramayu Regency, it has become an indisputable obligation that non-formal education needs to be strengthened from all dimensions supported by the Indramayu Regional Government. The implementation of Diniyah Takmiliyah's political education policy in Indramayu Regency has a legal basis:

1. Regional Regulation of Indramayu Regency Number 33 of 2016 concerning Work Procedures of the Regional Secretariat (Regional News of Indramayu Regency Number 33 of 2016);

2. DPA of Regional Secretariat of Regional Secretariat of Indramayu Regency in 2018;

3. Indramayu Regency Youth Vision Implemented in Improving Quality Human Resources Based on Religious Teachings, Science and Technology and Cultural Values

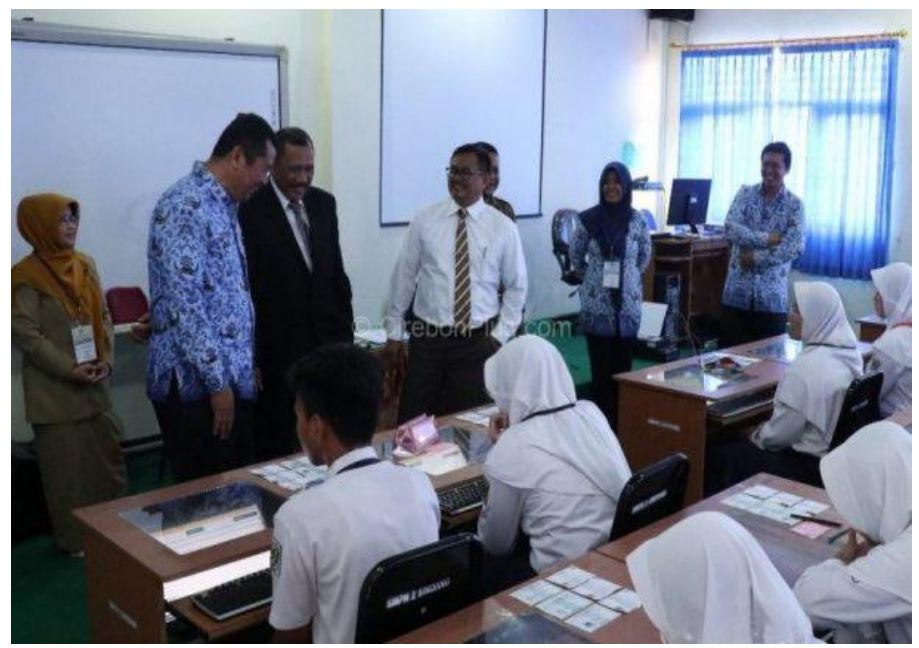

Figure 3:- Implementation Educational in Indramayu.

The implementation is carried out using the Socialization method which is based on the application of the Diniyah Takmiliyah curriculum and improvements are made by verifying the level of management of the madrasa head and teaching quality teachers. the affirmation of the activities of Diniyah Takmiliyah Awaliyah above hereby can be underlined that the overall implementation of educational politics in the Indramayu Regency is inseparable from the vision and mission of the Regent and Deputy Regent of 2016-2021 as outlined in the regional medium-term development plan (RPJMD) is religius, advanced, independent and prosperous as well as created with regional advantages ".

The educational policy direction of Indramayu Regency above, was formulated in the main tasks and functions of the Education Office as stipulated in the Regional Regulation of Indramayu Regency number 11 of 2005 concerning the establishment of the Regional Work Unit of the Indramayu Regency, as well as the vision of the elected Regent for the period of 2016-2021 determined through the Regional Regulation Indramayu Regency Number 5 of 2014 concerning the Medium-Term Regional Development Plan for 2016-2021, as well as the results of studies of actual issues that are developing, the District Education Office of Indramayu sets the vision as follows: "the requirement of the education of indramayu districts that have comparative advantages, religius", safe, obedient and innovative ". 
By establishing the vision formulation, it is expected that the implementation of educational services can shape and print superior and competitive human resources capable of realizing their role as adaptive and transformative social creatures capable of managing themselves and all the potential contained in the natural surroundings to be able to realize the vision of the regional government, namely the most advanced district in Indonesia.

Assessment of the Purpose and Targets of Political Education Policy in Indramayu Regency, As one of the efforts to realize the Indramayu community that is religious, advanced, independent and prosperous as well as the creation of regional excellence, where one of its efforts is to implement MDTA education policy, the researcher makes observations and interviews with the community regarding implementation MDTA's Perda policy.

Discussion, Indramayu Regency in relation to how local policies in the context of implementing the decentralization of education policy, referring to Perda No. 12 of 2012 concerning MDTA Compulsory Education, the opportunity to achieve educational goals is largely within the responsibility of local governments. Thus the focus of this research is; (1) Implementation of local government authority in the politics of education, (2) the role and function of local governments in the implementation of education political policies, and (2) types of local government policies in the field of education.

Law No. 22/1999 stipulates 11 fields that must be implemented by regencies / cities, one of which is education and culture. Government Regulation Number 25 of 2000 does not specify the authority of the Regency / City because basically all authority that is not exercised by the Government and Province is the authority of the Regency / City.

1. The authority of the regional government in education, referring to the aforementioned Laws and Government Regulations, the authority of the Regency / City in the field of education can be identified into the following authorities: organizing school education, non-school education, sports education, culture, public administration, organizations and management, staffing, and control and supervision. These authorities are further broken down into authorities

2. Roles and functions of local government, Local government has a very strategic role and function in improving and developing education in the region. Improvement and development of education in the region, highly dependent on the management and politics of education in the area. Therefore, the willingness of the local government to manage education is very significant.

3. Regional government policies in the field of education. Implementation of education in the regions must continue to ignore the four basic strategies of national education which include, equity education, quality improvement, and relevance and efficiency. (LIPI, 2002). District and city governments can improvise and education programs, however, they must pay attention to the objectives of national education, namely education for all people equally and directed towards quality improvement that is efficient and has relevance as needed.

The cost of education comes from the government, family, and other non-government organization sources. (Suryadi, 2002). Act No. 20 of 2003 concerning the National Education system has actually mandated the importance of budget allocation for funding and education development. In article 49 paragraph (1) it is stated that "Education funds other than teacher salaries and official education costs are allocated a minimum of $20 \%$ of the State Revenue and Expenditure Budget (APBN) in the education sector and a minimum of $20 \%$ of the Regional Revenue and Expenditure Budget (APBD). (National Education System Law, 2003). Unfortunately, the mandate that clearly has a legal basis and umbrella with various excuses and reasons to date has still not been able to be carried out optimally.

4. Empowerment of MDTA, Empowerment has penetrated in various fields and aspects of human life, including education. Cook and Macaulay in Mulayasa (2002) provide the definition of empowerment as an important tool to improve organizational performance through the dissemination of decision making and responsibility. Thus, it will encourage the involvement of employees in decision making and responsibility. In the world of education empowerment is aimed at students, teachers, principals and administrative staff.

\section{Conclusions:-}

The political policy of education in Indramayu Regency is based on Perda No. 12 of 2012 concerning the Mandatory Learning of Madrasah Diniyah Takmiliyah Awaliyah is a good intentions and a political will together between the Regent and the People's Representative Council of Indramayu. The gap between the objectives and policy performance is minimized by the District Education Office together with relevant stakeholders, especially MDTA managers. After making observations, interviews and discussions with informants and research subjects and then 
analyzed based on the policy evaluation model, the following are some conclusions that can be raised by researchers:

1. Contents of the Education Policy contained in Perda No. 12 of 2012 conceptually regulating the compulsory education of Madrasah Dinniyah Takmiliyah has been carried out consequently by the Regent, DPRD and the District Education Office of Indramayu. Even though there were obstacles related to implementation in the field, the Regent and Deputy Regent have tried their best to provide reinforcement to this Perda through a Circular requiring all students in Indramayu to follow MDTA. Furthermore, MDTA diploma is a prerequisite that must be possessed by every student who wants to continue to the next level of education, namely SMP / MTs in Indramayu Regency. The contents of the policy contribute to increasing the quantity and quality of MDTA in Indramayu. This means that the contents of the policy have been understood and implemented by various parties.

2. Implementation of educational political policies that are in favor of the community and accommodate the political interests of regional leaders including the components of Program Support (input), Program Implementation (process), Output Program Results (output), Program Benefits (outcomes), and Program Impact (impact) ). This has been carried out by the Indramayu Regional Government by considering the community's uniqueness and the geographical situation of the Indramayu Regency. The Regent and Deputy Regent through the Department of Education have implemented the Regional Regulation consequently.

3. Implementation of education political policies regulated in Perda No. 12 of 2012 consistently creates equality and get educational opportunities, allocation of education costs and does not burden parents. This Perda is an effort to prepare Indramayu's young generation with morality and personality based on Pancasila. Even though the constraints relate to budget politics, the Regency Government has tried to increase the budget so that the implementation of the compulsory education program can be implemented well.

4. Implementation of education political policies organized by Indramayu Regency in accordance with Perda No. 12 of 2012 as a political promise turned out to have drawn a lot of appreciation from citizens and education activists. However political education policies in the era of regional autonomy and the decentralization of education implemented by their respective regions all depend on the people being the policy targets. Generally

5. The implementation of this political education policy has reached the target and it is proper to be given support so that it can exceed the targets expected together.

6. As a result of the evaluation, the researcher provides recommendations so that no matter how good a policy needs to be improved continuously and continuously by referring to the concept of Plan, Do, Check, Action (PDCA) in order to get input and criticism and suggestions from all parties. If so, the improvement in the implementation of political education policy in order to prepare future generations of noble character is an absolute thing.

\section{Refrences:-}

1. Bailey K.D., (1978) Method of Social Research, London Free Press, 1978

2. Bapenas, Guidelines for Implementing Program Logic Framework and Determining Indicators. (Jakarta, Bappenas, 2010). h 23

3. Blair, Tony., (1999) Modernizing Government. With Paper Presented to Parliament. (By the Prime Minister and the Minister for the Cabinet Office and by the Command of Her Mayesty.

4. Borg, Walter R and Meredith D. Gail, (1989) Educational Research: An Introduction to 5th Edition, New York: Longman

5. Bryman, Alan and Robert G Burgess. (2002) Analyzing Qualitative Data. London: Routledge

6. Daymon, Christine and Immy Holloway (2002) Qualitative Research Methods in Public Relations and Marketing Communications. London: Routledge

7. Dunn, Wiliam N, (2003) Penganatar Public Policy Analysis (Yogyakarta: Gajahmada University Press

8. Dwijiwijoto Riant Nugroho, (2003), Public Policy: Pharmacy, Implementation and Evaluation, Jakarta: Elek Computind

9. Jauch Laurance R. and William Glueck, Business Policy and Strategic Management (Singapore: McGraw Hill, 1988). H.366-367.

10. Mulyasa E., (2003) School Based Management (Bandung: Remadja Rosdakarya, 2003). H.133.

11. Muhadjir, Noeng. (2001) Philosophy of Positivism, Post Positivism and Post Modernism, edition II, Yogyakarta: Rake Sarasin

12. Tangkilisan, Hessen Nogi S, (2003), Public Policy Implementation, Yogyakarta: Lukman Offset.

13. Philips D.C ... (1983), After the Wake: Post Positive Educational Thought (Educational Researcher 12 Number 5). 
14. Person, Wayne., (2001) Public Policy: An Introduction to the Theory and Practice of Policy Analysis (United Kingdom: Edward Elgar Publishing, Ltd.

15. Royse David, Bruce A. Thyer, and Deborah K. Padgett. (2010), Program Evaluation: An Introduction, Fifth Edition, (Wadsworth, Cengage Learning

16. Starling, Grover. (2008) Managing The Public Sector, (Boston: Thomson Wadsworth

17. Wirawan, (2011), Evaluation: Theory, Models, Standards, Applications and Professions. (Jakarta, Rajawali Press). 